Sebastian Chudak

Uniwersytet im. Adama Mickiewicza

\title{
KOMPETENCJA MEDIALNA UCZNIÓW I NAUCZYCIELI JĘZYKÓW OBCYCH JAKO CZYNNIK WPŁYWAJĄCY NA POZIOM ICH KOMPETENCJI INTERKULTUROWEJ
}

\section{The effect of the media literacy of foreign language students and teachers on their level of intercultural competence}

\begin{abstract}
Intercultural competence is an expected outcome in language learning and teaching in our contemporary world. However, studies show foreign language teachers are not always aware of the importance of this goal for many reasons, the most important of which seems to be the low level of their own intercultural competence. The aim of this article is to discuss the possibilities of increasing the intercultural competence of foreign language teachers and students. . The correlation between media literacy and the development of intercultural competence is discussed.
\end{abstract}

Nauczyciel jest niewątpliwie jednym z najważniejszych elementów układu glottodydaktycznego, a jego wzajemna relacja z uczniem ten układ konstytuuje. Jakkolwiek możliwe są oczywiście procesy autodydaktyczne (także z wykorzystaniem szeroko rozumianych „urządzeń nauczających”, np. wyposażonych w odpowiednie oprogramowanie komputerów, lub tzw. samouczków), a autonomia ucznia uznawana jest za istotny cel edukacji, to jednak - jak wskazuje m.in. Pfeiffer (2001: 20-23) - nauczyciel „nie może [...] być zastąpiony całkowicie, tj. na wszystkich etapach i płaszczyznach, we wszystkich funkcjach i aspektach nauczania".

Współczesna dydaktyka stawia przed nauczycielami języków obcych spore wyzwania. Aby spełniać wszystkie przypisywane im funkcje i związane z nimi zadania, muszą oni posiadać rozległą wiedzę oraz szeroką paletę umiejętności. 
Jak pisze Pfeiffer (2001: 121-141), nauczyciel jako „kreator procesów glottodydaktycznych" powinien wypełniać następujące podstawowe funkcje: organizacyjną, podawczo-nauczającą, kreacyjną, aktywizacyjną, indywidualizacyjną, motywacyjną, sterowniczą, kontrolną, interpretatora kultury, opiekuna-wychowawcy. Aby wypełniać je wszystkie, nauczyciel musi posiąść różnorakie kompetencje, do których zalicza się kompetencję językową, metodyczną, krajo- i kulturoznawczą, pedagogiczną i medialną (por. Pfeiffer, 2001: 194-199; Zawadzka, 2004; Godlewicz-Adamiec, 2008: 184-186; Nowacka, 2010: 265-270).

Obok kompetencji językowych, dydaktycznych i pedagogicznych, szczególnie dużo uwagi poświęca się w ostatnich latach ściśle powiązanej z kompetencją krajo- i kulturoznawczą kompetencji interkulturowej nauczycieli (por. Wilczyńska, 2005: 25-26; Torenc, 2008: 238-239). Współczesny nauczyciel ma bowiem nie tylko nauczać struktur gramatycznych czy też nowych jednostek leksykalnych bądź rozwijać sprawności językowe uczniów. Ma on także przekazywać wiedzę na temat obcych kultur, w tym kultury kraju/krajów języka docelowego, a nawet pośredniczyć pomiędzy kulturą docelową a kręgiem kulturowym, z którego wywodzą się jego uczniowie. Język i kultura to, jak bowiem współcześnie się uważa, zjawiska, których nie da się rozdzielić, gdyż język to dziedzina kultury, jej produkt, będący nie tylko nośnikiem kultury, ale także jej współtwórcą (por. Zawadzka, 2004: 185; Wilczyńska, 2005: 17-20). Pamiętać należy przy tym jednakże o tym, że wspominana wyżej kompetencja interkulturowa nie ogranicza się jedynie do kultury języka docelowego i oznacza szeroką paletę cech (np. otwartość, wrażliwość, tolerancja dwuznaczności) i umiejętności (np. umiejętność negocjowania i rozwiązywania konfliktów) przydatnych w kontaktach z przedstawicielami różnych kultur (por. Byram/Morgan, 1994; Bolten, 2007: 86).

Nauczyciel języków obcych musi zatem dysponować wiedzą na temat kraju/krajów, w których używa się nauczanego przez niego języka. Sama wiedza to jednak zbyt mało. Nauczyciel musi być sam kompetentny i doświadczony interkulturowo, aby móc dokonać właściwej selekcji treści przekazywanych uczniom i aby wychowywać ich interkulturowo, tj. rozwijać u nich odpowiednie cechy i umiejętności. Dla potwierdzenia powyższej tezy wskazać można choćby na powstałe $w$ ubiegłych latach dokumenty, materiały pomocnicze i narzędzia refleksji przeznaczone dla przyszłych nauczycieli języków obcych, w których wspomniane zakresy wiedzy i umiejętności zajmują znaczące miejsce. W „Europejskim profilu kształcenia nauczycieli języków” (Kelly/Grenfell, 2006) zwraca się uwagę na konieczność doświadczania przez przyszłych nauczycieli środowiska interkulturowego i wielokulturowego, a także poszanowanie różnorodności kultur oraz postrzeganie samego procesu zdobywania wiedzy o innych kulturach jako wartości. Z kolei „Europejskie portfolio dla stu- 
dentów - przyszłych nauczycieli języków" (Newby et al., 2007) akcentuje konieczność rozwinięcia przez nauczyciela umiejętności ewaluacji i doboru takich materiałów i zadań, które wzbudzają w uczniach zainteresowanie kulturą docelową i sprzyjają okazjom do dokonywania porównań między własną kulturą a kulturą docelową; które będą dawały możliwość bezpośredniego doświadczania tejże kultury także poza szkołą; które pozwolą im rozwinąć umiejętność oceny wiedzy uczniów na temat faktów i wydarzeń kulturowych w społecznościach posługujących się językiem docelowym itp.

Celem niniejszego artykułu jest refleksja nad tym, w jakim stopniu nauczyciele języków obcych przygotowani są do realizacji tak kompleksowego zadania, jakim jest rozwijanie kompetencji interkulturowej uczniów. Ponieważ istnieje uzasadniona obawa, że ich przygotowanie nie jest optymalne, to kolejnym celem jest tu wskazanie możliwości poprawienia istniejącego stanu.

\section{Czy nauczyciele są przygotowani do realizacji stawianych im współcześnie zadań?}

Aktualne badania wskazują niestety na to, że poziom przygotowania nauczycieli do realizacji stawianych im współcześnie zadań nie jest zbyt wysoki (por. Bandura, 2003; Mackiewicz, 2006; Gabryś-Barker, 2006; Chłopek, 2009; Chudak, 2013b). Nauczyciele nie zawsze mają świadomość tego, w jaki sposób można rozwijać wrażliwość uczniów na inność kulturową, ich umiejętność obserwacji i porównywania, empatię i inne cechy, składające się na to, co rozumiemy pod pojęciem kompetencji interkulturowej. W ramach studiów filologicznych przyszli nauczyciele zdobywają wprawdzie rozległą wiedzę z zakresu wspomnianej już kultury kraju/krajów języka docelowego, nie mają jednak co potwierdza obserwacja praktyki i analiza programów studiów - zbyt wielu możliwości do zbierania doświadczeń związanych z kulturą docelową, nie wspominając o doświadczeniach wychodzących poza krąg kultury docelowej.

Problem stanowi już samo zdefiniowanie pojęcia „kultura docelowa”, a precyzyjne określenie zakresu potencjalnie ogromnej wiedzy, którą miałby sobie przyswoić nauczyciel, wydaje się praktycznie niemożliwe. Jeszcze trudniej byłoby przewidzieć wszystko to, co może być pomocne w kontaktach z przedstawicielami innych kultur. Stąd, wydaje się, że bardziej celowe od przekazywania konkretnej wiedzy i dywagowania nad tym, który jej zakres może okazać się przydatniejszy w komunikacji interkulturowej, będzie rozwijanie takich umiejętności, które pozwolą także po zakończeniu studiów na poszerzanie zdobytych już podstawowych kompetencji (initial competence). Taki model postuluje - nie wskazując wprawdzie konkretnie na kompetencję 
interkulturową - Wysocka (2003), która zakłada jednocześnie pesymistycznie, jakkolwiek nie bez dużej dozy realizmu, że wspomniane kompetencje mogą w przypadku wielu nauczycieli nigdy nie osiągnąć poziomu profesjonalnego (professional competence).

Obserwacja praktyki dydaktycznej oraz wyniki badań poziomu świadomości problemu wśród nauczycieli potwierdzają opinię, że nauczyciele języków obcych nie są w sposób właściwy przygotowani do realizacji stojących przed nimi zadań.

I tak np. Bandura (2003: 64-66) pisze, że „popularyzowanie wśród uczniów znajomości kultury/cywilizacji krajów, których języka się uczą" oraz „zachęcanie do kształcenia otwartości umysłu i pozytywnego nastawienia do mniej znanych kultur" zajmuje wprawdzie w opinii ankietowanych przez nią nauczycieli stosunkowo wysokie miejsce $w$ hierarchii celów nauczania języków obcych oraz, że „nauczanie kultury nie jest kojarzone wyłącznie z przekazywaniem wiedzy”, lecz także z "rozwijaniem postawy otwartości i tolerancji w stosunku do innych narodów i kultur". Z drugiej strony wskazuje jednak na to, że „w Polsce dwa najczęstsze sposoby 'nauczania kultury' polegają na prostym przekazywaniu wiedzy, opinii i doświadczeń, bez konieczności zaangażowania uczniów”, że „daleko rzadziej niż w innych krajach polscy nauczyciele posługują się multimediami, lub komentują przekaz w mediach" oraz że „polscy uczniowie są rzadko zachęcani do pracy samodzielnej” także w zakresie rozwijania kompetencji interkulturowej.

Wyniki badań przeprowadzonych przez Mackiewicza (2006: 34-36) pokazują natomiast, że większość ankietowanych przez niego uczniów nie czuje się właściwie przygotowana do radzenia sobie w sytuacjach kontaktu z przedstawicielami obcych kultur, w tym kultury docelowej (w tym przypadku krajów niemieckojęzycznych), co wynika z faktu, że lekcje języka obcego, w których uczestniczyli/uczestniczą, nie stanowiły/stanowią dla nich ani źródła informacji krajo-, realio- i kulturoznawczych, ani tym bardziej „wiedzy interkulturowej”. Co ciekawe, ankietowani przez Mackiewicza nauczyciele uważają się za generalnie dobrze przygotowanych do przekazywania swoim uczniom wspomnianej wiedzy, wykazują się jednak także krytycyzmem wobec własnych działań dydaktycznych (por. Gabryś-Barker, 2006: 95). Jak jednak dowodzą inne badania np. ich gotowość i motywacja do refleksji nad własnym tłem kulturowym - co jest istotnym elementem kompetencji interkulturowej (por. Chudak, 2013b) jest, o ile w ogóle rozwinięta, to raczej niska (por. Chudak, 2012a).

Istotnym problemem, na który wskazuje m.in. Chłopek (2009: 65-66), jest także nadmierne poleganie na tym, co podają autorzy używanego na lekcjach podręcznika. W konsekwencji tematy, które nie są w nim poruszane, bywają całkowicie pomijane. Faktem jest, że podręczniki zawierają liczne 
deficyty w zakresie zawartej w nich wiedzy na temat kultury docelowej (por. Chudak, 2010a: 229-230; Chudak, 2010b: 63-73), a informacji o kulturach innych niż docelowa nie zawierają praktycznie wcale. Niewiele $w$ nich też zadań, które sprzyjałyby rozwijaniu cech i zachowań pożądanych w kontaktach z obcymi kulturami. Z kolei nauczyciele mają silną skłonność do tego, aby trzymać się ściśle tego, co przedstawione w podręczniku (por. Chudak, 2007a: 139-141). Tym bardziej pozytywnie należy ocenić to, że przynajmniej część z nich dostrzega deficyty używanych przez nich podręczników i stara się owe deficyty niwelować, włączając do repertuaru stosowanych przez siebie materiałów glottodydaktycznych materiały pozapodręcznikowe.

\section{Jak zatem edukować (przyszłych) nauczycieli?}

Jak wynika z cytowanych powyżej wyników badań poziomu świadomości problemu czy też poziomu kompetencji czynnych zawodowo nauczycieli, obecna sytuacja daleka jest od optimum. Obawiać można się, że znaczna część uczniów nie otrzymuje w ramach kursów językowych, w których bierze udział, ani wiedzy niezbędnej do zrozumienia kultury docelowej, ani tym bardziej nie nabywa cech i nie rozwija umiejętności przydatnych w kontaktach z przedstawicielami innych obcych im kultur. Aby zmienić ten stan, należy zastanowić się nad tym, w jaki sposób systematycznie i efektywnie zwiększać kompetencje pracujących z nimi nauczycieli, tak aby poziom ich kompetencji był coraz bliższy wspomnianemu powyżej poziomowi profesjonalnemu (professional competence).

Taka ewolucja kompetencji jest możliwa - jak się wydaje - tylko wtedy, gdy nauczyciel jeszcze na etapie przygotowywania do wykonywania zawodu sam doświadczy istoty problemu poprzez bezpośrednie kontakty z różnymi kulturami, w tym także z kulturą docelową, rozwinie w sobie motywację do aktywnego obserwowania tychże kultur, przyjmie postawę swoistego badacza kultury, który z niesłabnącą ciekawością będzie stale, nawet (a raczej przede wszystkim) po zakończeniu swojej edukacji zawodowej z dużym zaangażowaniem kontynuował w autonomiczny, świadomy i refleksyjny sposób pracę nad tą właśnie kompetencją. Konieczne są także rozwijanie repertuaru technik pracy z uczniami i - co szczególnie istotne - umiejętność doboru i właściwej dydaktyzacji materiałów uzupełniających treści zawarte w podręcznikach. 


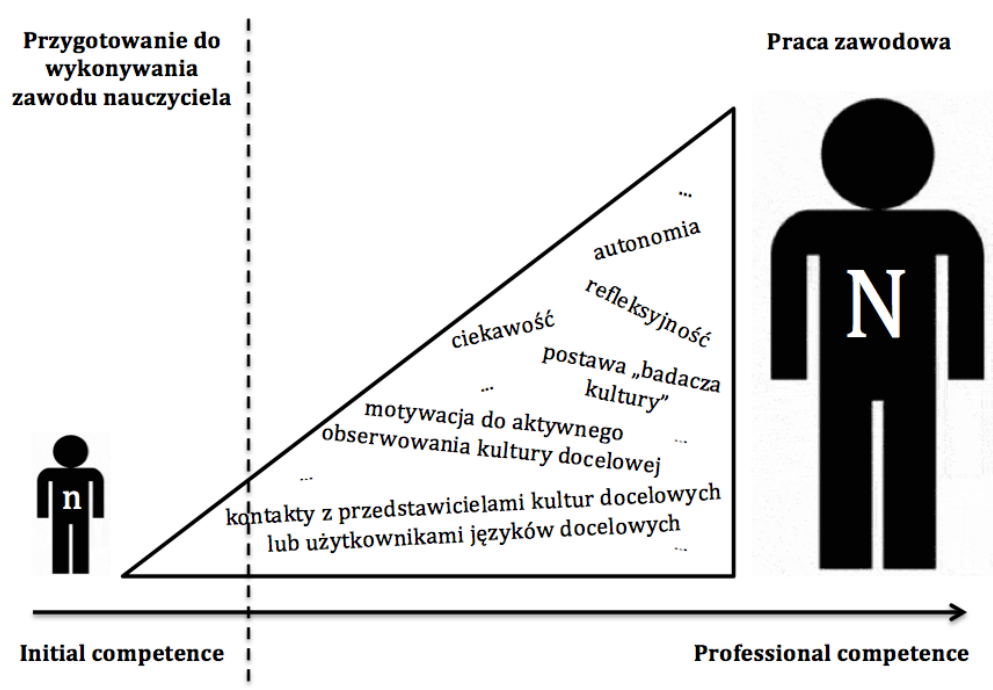

Schemat 1: Czynniki wpływające na rozwój kompetencji interkulturowej nauczyciela (opracowanie własne).

W kwestii wspomnianego powyżej bezpośredniego kontaktu z obcymi kulturami (w tym z kulturą docelową) można optymistycznie założyć, że jest on w dzisiejszych czasach nie tylko szczególnie łatwy (np. w trakcie podróży zagranicznych, za pośrednictwem nowoczesnych mediów, portali społecznościowych itp.), ale nawet trudny do uniknięcia (ostatecznie nawet nie opuszczając granic własnego kraju, spotykamy przedstawicieli obcych kultur i konfrontujemy się z odmiennymi zachowaniami, zwyczajami, poglądami itp.). Szczególnie wiele możliwości mają w tym zakresie studenci, w tym oczywiście także i ci, którzy przygotowują się do wykonywania w przyszłości zawodu nauczycieli języków obcych. Wyjazdy na studia, np. w ramach programu Socrates-Erasmus - jak pisze Mackiewicz (2006: 37) - to obecnie standard. Potwierdzają to też dane statystyczne wskazujące na stały wzrost liczby uczestników (także osób uczących się języków obcych, filologów i nauczycieli języków) wspomnianego programu (por. Zespół Programu Erasmus, 2007; Członkowska-Naumiuk, 2011), choć w odniesieniu do ogólnej liczby studiujących, którzy planują pracować w przyszłości jako nauczyciele, jest to liczba niska. Brak tu niestety precyzyjnych danych. Na taką tezę pozwala jednak obserwacja aktywności studentów we własnych grupach seminaryjnych, w których w ostatnich latach zwykle jeden (maksymalnie dwóch) na dziesięciu studentów podejmuje wyzwanie, jakim jest spędzenie semestru na zagranicznej uczelni. Osobiste zetknięcie się z inną kulturą jest z pewnością najlepszym sposobem jej poznania. Istotną 
kwestią pozostaje jednak poziom refleksji na temat zdobywanych doświadczeń. Zachodzi obawa, że nie zawsze jest on wystarczająco wysoki, że nie prowadzi w każdym przypadku do rozwinięcia cech i zachowań pożądanych w kontekście rozwijania kompetencji interkulturowej. Potwierdzają to także rozmowy ze studentami-uczestnikami programu. Dlatego celowym wydaje się wiązanie pobytów zagranicznych studentów z zadaniami obserwacyjnymi, pisaniem sprawozdań lub pamiętników itp. (por. Chudak, 2010a: 234-235).

Od kompetentnych dydaktyków oczekuje się oczywiście także umiejętności właściwej selekcji materiałów glottodydaktycznych. W tym kontekście niepokój budzi fakt, na który wskazuje m.in. cytowana już powyżej Chłopek (2009: 64), braku umiejętności wyboru i zastosowania na lekcjach takich materiałów, które pomagałyby w rozwijaniu kompetencji interkulturowej uczniów:

„[...] chociaż nauczyciele nie oceniają swoich podręczników zbyt wysoko, nie używają materiałów uzupełniających zbyt często. [...] nauczyciele zazwyczaj wykorzystują w swojej pracy piosenki, projekty indywidualne lub grupowe i zaprojektowane przez siebie ćwiczenia. Rzadziej korzystają z takich materiatów, jak gazety i czasopisma, programy telewizyjne/ radiowe, filmy, reklamy lub literatura obcojęzyczna. Warto jednak zauważyć, że rzadziej używane materiały mają w rzeczywistości wyższy potencjał rozwijania wiedzy kulturowej. [...] wspomniane przez nauczycieli materiały tak naprawdę $w$ niewielkim stopniu rozwijają wiedzę socjokulturową i pragmatyczną [...], tylko przede wszystkim przyczyniają się do rozwoju kompetencji czysto językowych."

Fakt rzadkiego stosowania materiałów autentycznych, względnie nie zawsze optymalnego doboru pomocy dydaktycznych, potwierdzają także wyniki badań przeprowadzonych przez Adamczak-Krysztofowicz (2003: 219). Wynika z nich, że najczęściej wybierane przez nauczycieli materiały uzupełniające to artykuły prasowe lub teksty z podręczników (por. Chudak, 2007b: 15), które przez ankietowanych uczniów określane są jako przestarzałe lub zbyt łatwe. W ich opinii do rozwoju kompetencji interkulturowej lepiej służą materiały audiowizualne, tj. filmy czy też programy telewizyjne (ibid. 215). Paradoksalnie uczniowie wyraźniej niż nauczyciele dostrzegają potencjał takich materiałów, które $w$ ich ocenie są nie tylko atrakcyjne, ale przede wszystkim aktywizujące i dające wgląd w obcy im kulturowo świat, w tym także w kulturę docelową - który jakkolwiek tylko pośredni, to jednak intensywniejszy niż w przypadku li tylko lektury artykułów prasowych lub oglądania zdjęć (por. Chudak, 2007b: 15-16). Tymczasem zainteresowanie dydaktyków języka materiałami audiowizualnymi wydaje się znikome. Artykuły z propozycjami ich wykorzystania na lekcjach występują w ilościach iście 
homeopatycznych (por. np. artykuły w ostatnich rocznikach „Języków Obcych w Szkole"), a ich jakość zwykle także pozostawia do życzenia.

$\mathrm{Na}$ temat potencjału materiałów filmowych (szczególnie w związku z rozwijaniem kompetencji interkulturowej ucznia) powiedzieć można wiele (por. Chudak, 2008/2013d; Welke/Chudak, 2010). W kontekście niniejszego artykułu istotniejsza jednak od wymieniania dość oczywistych argumentów za ich użyciem wydaje się refleksja nad tym, co jest przyczyną ich zbyt rzadkiego użycia oraz prezentacja sposobów rozwiązania tego problemu.

W znalezieniu odpowiedzi na pytanie o przyczyny rzadkiego zastosowania materiałów audiowizualnych na lekcjach pomocne okazały się własne badania ankietowe prowadzone w roku akademickim 2010/11 i 2011/12 wśród studentów studiów uzupełniających magisterskich filologii germańskiej na Uniwersytecie im. A. Mickiewicza w Poznaniu (próba 50 osób), z których znaczna część (65\% osób ankietowanych) jest już czynna zawodowo. Badania te wykazały, że głównymi przyczynami takiego stanu rzeczy są ograniczenia czasowe (tak podaje $94 \%$ osób ankietowanych) oraz presja związana z przygotowaniem uczniów do oczekujących ich egzaminów (tak podaje $84 \%$ osób ankietowanych). Wśród innych przyczyn stosunkowo często wymieniane są trudności związane z wyborem odpowiednich materiałów (54\% udzielonych odpowiedzi), z dostępem do nich (46\% udzielonych odpowiedzi) oraz z ich dydaktyzacją (42\% udzielonych odpowiedzi), co wskazuje na deficyty $w$ zakresie kompetencji medialnej ankietowanych osób. Należy obawiać się, że deficyty w zakresie tej kompetencji są także przyczyną tego, że młodzi nauczyciele wprawdzie postrzegają materiały audiowizualne jako źródło wiedzy krajo- i kulturoznawczej, a ich oglądanie i analizę jako przyczynek do rozwoju (także własnej) kompetencji interkulturowej, ale w rzeczywistości z nimi nie pracują (ani na lekcjach, ani w ramach samodoskonalenia zawodowego). Potwierdzają to dość zaskakujące jak na początek XXI wieku zadawane przez wspomnianych studentów pytania typu, gdzie można znaleźć odpowiednie filmy lub wypowiedzi świadczące o nieznajomości nawet klasycznych produkcji filmowych, aktorów i reżyserów itp.

\section{Czy nauczyciele są (nie)kompetentni medialnie?}

Nauczyciel musi obecnie wyjść z epoki Gutenberga i nauczyć się wykorzystywać potencjał mediów, które ma do dyspozycji. Innymi słowy - musi on być nauczycielem kompetentnym medialnie. Już przed ponad dziesięciu laty Pfeiffer (2001: 198) pisał, że „nauczyciel nie może nie umieć obsługiwać komputera, korzystać z Internetu i poczty elektronicznej”, gdyż "taka niechętna mediom rezy- 
gnacyjna postawa wzbudzi podejrzenie uczniów o nieudolność, wygodnictwo, a nawet zacofanie dydaktyczne nauczyciela". Wskazywał też na to, że „przed taką oceną trzeba się bronić.” Tymczasem, nawet wśród stosunkowo młodych nauczycieli, wywodzących się z pokolenia ludzi o zmienionych już przez rozwój cywilizacyjny nawykach związanych z odbiorem i przetwarzaniem informacji (por. Chudak, 2013c: 16-19), można zaobserwować taką właśnie "rezygnacyjną postawę”, i to nawet nie w stosunku do komputerów i Internetu, ale - co zaskakuje - nawet w odniesieniu do wspomnianych mediów audiowizualnych. Potwierdzają to wyniki wspomnianych powyżej badań własnych i obserwacja podejmowanych przez studentów działań dydaktycznych (np. w ramach praktyk pedagogicznych) oraz ewaluacja ich propozycji dydaktycznych w pracach licencjackich i magisterskich.

Czy zatem nauczyciele przechodzą w ramach przygotowujących ich do wykonywania zawodu studiów odpowiedni trening w zakresie kompetencji medialnej? Odpowiadając na to pytanie, należy zwrócić uwagę na to, że kompetencja ta może być pojmowana w dwojaki sposób:

- w ujęciu podstawowym, jako „umiejętność obsługi mediów” i „znajomość ich wielorakich funkcji dla efektywnego stosowania w procesie nauki języka" (Pfeiffer, 2001: 198), tj. połączenie kompetencji technicznej (tzn. umiejętności obsługi urządzeń technicznych), semantycznej (tzn. umiejętność selekcjonowania, interpretowania, rozumienia informacji przekazywanych/ zdobywanych za pośrednictwem mediów i konstruowania na tej podstawie wiedzy) i pragmatycznej (tzn. umiejętność aktywnego i odpowiedzialnego używania mediów w interakcji socjalnej itd.) (por. Biechele, 2004: 156; Ester, 2007);

- w ujęciu - co w kontekście pracy nad rozwijaniem kompetencji interkulturowej (nauczycieli i uczniów) szczególnie ważne - poszerzonym, jako „interkulturowa kompetencja medialna” (Luchtenberg, 2003/2005), tj. umiejętność krytycznej refleksji na temat języka i roli mediów, sposobów prezentacji różnorodnych tematów w kręgu kultury docelowej, porównywania wspomnianych aspektów z mediami we własnym kręgu kulturowym.

W odniesieniu do pierwszego z wymienionych wyżej ujęć można stwierdzić, że przyszli nauczyciele nie zawsze zdają sobie sprawę z tego, jak wielowymiarowym zjawiskiem jest opisywana tutaj kompetencja, że ich wiedza w tym zakresie jest niezbyt usystematyzowana, a nawet pełna luk (por. Biechele, 2004: 156-159). Z drugiej zaś strony, mają oni stosunkowo wysoką samoocenę własnych umiejętności (por. Marciniak, 2012), co jak się wydaje, 
wynika głównie z braku świadomości kompleksowości tej kompetencji i sprowadzania jej głównie do obsługi różnych urządzeń technicznych.

W odniesieniu do drugiego z wymienionych wyżej ujęć można zaryzykować stwierdzenie, że większość nauczycieli języków obcych, którzy edukację zawodową przeszli w swoim kraju ojczystym i tylko stosunkowo rzadko przebywali w kraju/ krajach, w których używa się języka docelowego, ma poziom kompetencji zbliżony do poziomu kompetencji swoich uczniów, tj. że jest to poziom daleki od poziomu kompetencji medialnej rodzimych użytkowników danego języka (por. Luchtenberg, 2005: 605-606).

Wszystko to potwierdza z jednej strony obserwacja praktyki szkolnej, w której - jak wspomniano już wyżej - niektóre media nie pojawiają się wcale lub pojawiają się rzadko, przy czym ich potencjał nie jest wykorzystywany we właściwy sposób, oraz analiza wyników pracy studentów, którzy w ramach przygotowania do zawodu otrzymują różnego rodzaju zadania związane z użyciem mediów i dydaktyzacją treści przez nie transportowanych. Konsekwencją takiego stanu rzeczy jest zaprzepaszczanie potencjału mediów w kontekście rozwijania kompetencji docelowych (w tym kompetencji interkulturowej i medialnej) uczniów i brak, bądź znikoma ilość, efektywnych działań skierowanych na samodoskonalenie wśród nauczycieli. Gdy chodzi o to ostatnie, to przyszli nauczyciele wymieniają wprawdzie różnego rodzaju media (w tym najczęściej wideo/DVD) jako pomoc w autonomicznych działaniach skierowanych na rozwój własnych kompetencji (por. Biechele, 2004: 164). Ponieważ nie mają jednak wystarczająco rozwiniętej kompetencji medialnej, która z jednej strony jest celem autonomicznego uczenia się, z drugiej zaś strony umożliwiającym je instrumentem (ibid. 167), to ich działania nie przynoszą oczekiwanych wyników.

\section{Wnioski}

Podsumowując dotychczasowe rozważania można stwierdzić, że rozwój kompetencji medialnej ma silny wpływ na rozwój kompetencji interkulturowej, gdyż prowadzi do intensyfikacji kontaktów z obcymi kulturami, w tym z kulturą docelową, a przez to prowokuje do refleksji nad własnym kręgiem kulturowym i tymi kulturami, do porównywania i wyłaniania (pozornych) podobieństw lub różnic itd. 


\section{(interkulturowa) kompetencja medialna}
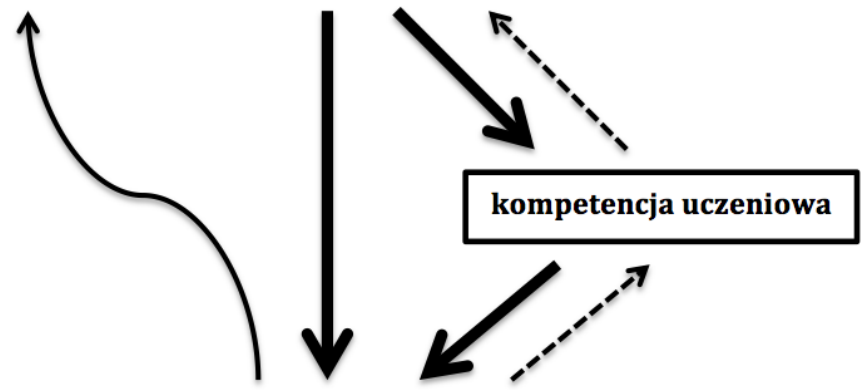

kompetencja interkulturowa

Schemat 2: Związek pomiędzy (interkulturową) kompetencją medialną a kompetencją uczeniową i kompetencją interkulturową (opracowanie własne).

Ma on także silny wpływ na rozwój kompetencji uczeniowej (rozwój i trening strategii/technik przydatnych w autonomicznej pracy z mediami), co w konsekwencji przekłada się na umiejętność samodzielnej pracy nad własną kompetencją interkulturową. Wszystko to dotyczy zarówno uczniów (rozwój autonomii ucznia), jak i nauczycieli (autonomiczne samodoskonalenie zawodowe). Wysoko rozwinięta kompetencja uczeniowa (duża świadomość roli mediów w procesie uczenia się języka, poszukiwanie strategii/technik efektywnej pracy z mediami itp.) może być przy tym bodźcem do rozwoju kompetencji medialnej. Kompetencja interkulturowa może natomiast przyczyniać się do rozwoju kompetencji uczeniowej (konfrontacja z odmiennymi tradycjami edukacyjnymi, strategiami/technikami uczenia się itp.). Z całą pewnością przyczynia się ona także do rozwoju interkulturowego wymiaru kompetencji medialnej (cechy i zachowania rozwijane $\mathrm{w}$ trakcie pracy nad kompetencją interkulturową jako bodziec do rozwinięcia kulturowej refleksji nad mediami).

Można założyć, że (najlepiej regularny i częsty) kontakt z mediami i treściami przez nie przekazywanymi (w praktyce edukacyjnej i poza kontekstem zinstytucjonalizowanej edukacji) przyczynia się do poszerzenia wiedzy (na temat samych mediów, ale też na temat szeroko pojętej kultury docelowej $\mathrm{i}$ innych obcych kultur), a w połączeniu z refleksją na temat treści przekazywanych za pośrednictwem mediów, ich języka, funkcji itp., przyczynia się w dużej mierze do przyrostu kompetencji medialnej, a w konsekwencji także do przyrostu kompetencji interkulturowej. Na rozwój tych kompetencji ma wpływ także doświadczenie (związane z podtrzymywaniem za pośrednictwem mediów kontaktów, wyszukiwaniem i przetwarzaniem informacji, pro- 
dukcją własnych treści medialnych itp.), które wydaje się być bezpośrednio związane z ekspozycją na treści medialne (intensywniejszy kontakt z mediami może się bowiem przekładać na wzbogacanie doświadczeń i vice versa). Doświadczenie może naturalnie być zainspirowane refleksją na temat mediów lub obcych kultur i jednocześnie przyczyniać się do pogłębiania tejże refleksji. Związek wiedzy na temat mediów czy obcych kultur (w tym kultury docelowej) z refleksją na ich temat nie jest, podobnie jak wszystkie wymienione wyżej związki, oczywisty, ale jest możliwy i pożądany.

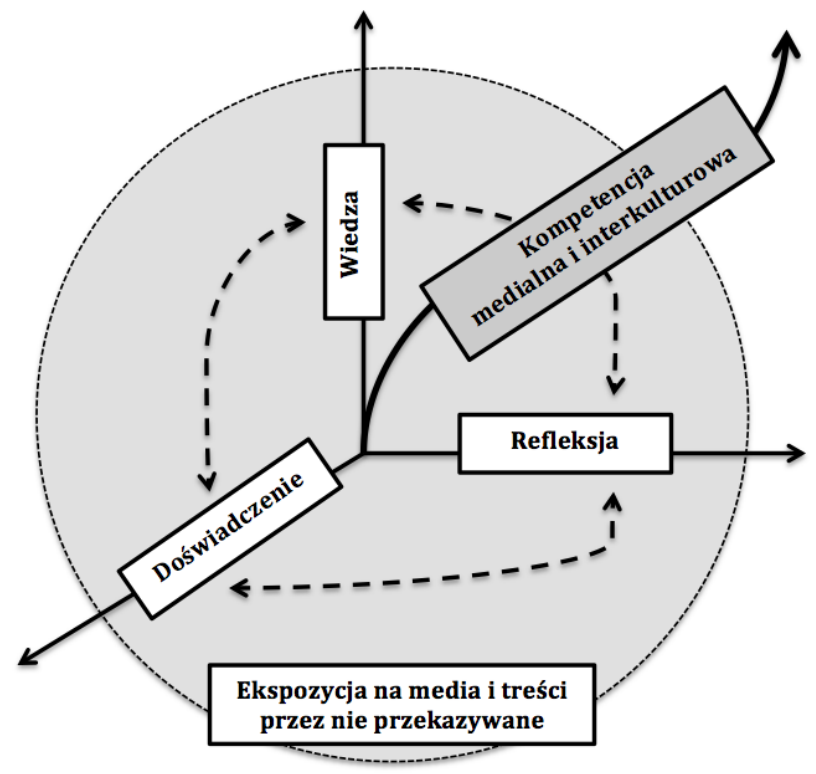

Schemat 3: Związek pomiędzy ekspozycją na media a kompetencją medialną i interkulturową (ucznia i nauczyciela), wiedzą o obcych kulturach (w tym o kulturze docelowej), refleksją na temat obcych kultur (w tym mediów) i doświadczeniem w kontaktach z przedstawicielami obcych kultur i z mediami (opracowanie własne).

Dopiero praca na wszystkich trzech wspomnianych płaszczyznach (tj. wiedzy, refleksji i doświadczenia) umożliwi optymalne rozwinięcie pożądanych kompetencji. Będzie ona jednocześnie odpowiadała założeniom dydaktyki konstruktywistycznej, według której z pełnym działaniem dydaktycznym mamy do czynienia dopiero wtedy, gdy dochodzi do połączenia umożliwiającego zdobycie osobie uczącej się (uczniowi i nauczycielowi) doświadczenia, spotkanie z wiedzą i refleksję (por. Wolff, 2002: 90-91). Znaczną rolę odgrywa tutaj oczywiście także wspomniana już umiejętność uczenia się, świadomość celów, inicjatywność itp., tj. wszystko to, co składa się na autonomię ucznia. 


\section{Konsekwencje dla praktyki edukacyjnej}

Opisane powyżej związki prowadzą do wniosku, że aby we właściwy sposób rozwijać docelowe kompetencje przyszłych nauczycieli, a w konsekwencji wspomaganych przez nich w procesie uczenia się uczniów, należałoby:

1. zachęcać i prowokować ich do (świadomej, uwieńczonej wnioskami) refleksji na temat mediów i zdobywania wiedzy o nich,

2. stwarzać możliwości do praktycznego doświadczenia mediów poprzez odpowiednie zadania i aktywności (poza-)lekcyjne, ale także

3. zwiększyć ich (obecnie w wielu przypadkach minimalną) ekspozycję na media i treści przekazywane za ich pośrednictwem.

Tym samym we wskazanym powyżej kontekście użycia materiałów audiowizualnych w pracy nad rozwojem kompetencji interkulturowej celowe wydaje się:

1. silniejsze niż ma to miejsce obecnie włączenie elementów medio- i filmoznawstwa do programów studiów filologicznych,

2. opracowanie (podobnie, jak ma to miejsce w przypadku zajęć z historii literatury) kanonów dzieł filmowych i metod pracy z nimi ( $w$ tym analizy środków wyrazu filmowego analogicznie do analizy środków wyrazu literackiego).

W przypadku (przyszłych) nauczycieli języków obcych, występujących w funkcji „przekaźników” wiedzy o kulturze docelowej i „pośredników” między kulturami, szczególnie istotna wydaje się być przygotowanie ich do samodzielnej (w celu stałego podnoszenia własnych kwalifikacji) i lekcyjnej (w celu podnoszenia kompetencji uczniów) pracy z wspomnianymi już materiałami audiowizualnymi. Konieczne jest tu zdobycie praktycznych doświadczeń zarówno w zakresie kompetencji technicznej, jak i semantycznej lub pragmatycznej, tj. rozwój podstaw kompetencji (initial competence) w ramach zajęć z metodyki nauczania języków obcych jako punkt wyjścia do pracy nad nią w ramach (samo-) doskonalenia zawodowego.

\section{Przykład z praktyki}

Za przykład działań skierowanych na osiągnięcie wymienionych wyżej celów podać można przeprowadzony w latach 2010-2012 projekt „Subtitles and Language Learning" (Projekt-Nr 504737-2009-LLP-FI-KA2-KA2NW; koordynatorem części projektu przeprowadzanej na UAM w Poznaniu była prof. dr hab. Teresa Tomaszkiewicz). W ramach projektu, studentom filologii angielskiej, nie- 
mieckiej i romańskiej UAM zaoferowane zostały zajęcia, na których w intensywniejszy sposób niż ma to zwykle miejsce pracowano z filmami (w tym szczególnym przypadku skupiając uwagę na potencjale, jaki niosą ze sobą podpisy do materiału filmowego). Wyniki ostateczne projektu nie zostały jeszcze opublikowane. Niemniej jednak zebrane podczas pracy ze studentami filologii germańskiej doświadczenia (por. Chudak, 2013d) pozwalają na stwierdzenie, że intensyfikacja pracy z materiałem audiowizualnym przez, np.:

- tworzenie podpisów do filmu odtwarzanego bez ścieżki dźwiękowej,

- uzupełnianie podpisów o informacje istotne dla osób nie(do)słyszących lub

- przygotowywanie informacji o widocznym na ekranie obrazie jako pomocy dla osób niewidzących,

okazała się być nie tylko niezwykle aktywizująca, ale przede wszystkim prowokująca osoby uczestniczące w projekcie do refleksji na temat środków przekazu filmowego, na które - jak osoby te wielokrotnie podkreślały wcześniej nie zwracały wystarczająco dużo uwagi, a przez to nie wykorzystywały maksymalnie potencjału informacyjnego zawartego w oglądanym przez nie materiale. Dopiero bowiem wyłączenie jednego z kanałów (dźwięku lub obrazu) wzmocniło ich uwagę na te aspekty interakcji między bohaterami filmu (głównie płaszczyznę niewerbalną i parawerbalną komunikacji), które mogą mieć znaczenie wtedy, gdy sami będą wchodzili w interakcje z przedstawicielami kultury docelowej lub innych obcych kultur (por. Chudak, 2013a). Uczestnicy projektu potwierdzali tym samym, że sama ekspozycja na materiał filmowy - nawet jeśli połączona z refleksją nad tematem poruszanym w filmie czy też wybranymi aspektami techniki filmowej - nie przyczyniła się w ich przypadku tak bardzo do pogłębienia ich refleksji na temat innych kultur, jak praktyczne zadania, które wymagały skupienia uwagi na wybranych aspektach pokazanej w prezentowanych im filmach interakcji pomiędzy przedstawicielami tychże kultur.

Z pewnością można przy tym założyć, że równie wartościowe byłoby zajęcie się filmami pokazującymi nie tylko sytuacje komunikacyjne, w których biorą udział rodzimi użytkownicy danego języka docelowego, ale także filmy pokazujące tzw. zderzenie kultur (culture clash) czy też zdarzenia krytyczne (critical incidents). Odpowiedni materiał filmowy można z pewnością znaleźć dla wielu konfiguracji kulturowych (przykłady filmów prezentujących takie sytuacje w kontekście polsko-niemieckim - por. Chudak, 2012b).

Pracy nad rozwojem kompetencji interkulturowej towarzyszyła w opisanym powyżej przypadku także refleksja na temat kompetencji medialnej. Naturalnie, wiedza i umiejętności z tego zakresu okazały się pomocne w realizacji poszczególnych zadań. Co jednak równie istotne, zadania obnażyły 
deficyty studentów w jej zakresie (np. w zakresie obsługi programów komputerowych służących do edycji podpisów filmowych i samego materiału filmowego) i stały się tym samym bodźcem do jej uzupełnienia. W dalszej perspektywie zarówno uzupełnienie wiedzy teoretycznej (jako forma eksplicytnego treningu strategicznego) i opisane doświadczenia (trening implicytny) mogą stać się przyczynkiem do samodzielnego, autonomicznego kontynuowania doskonalenia w zakresie opisywanych tutaj kompetencji.

\section{Podsumowanie}

Podsumowując powyższe rozważania można sformułować postulat o to, aby w ramach przygotowania nauczycieli do zawodu zwiększyć liczbę i podnieść jakość podejmowanych przez nich aktywności medialnych. Stanowiłoby to podwaliny pod ich przyszłą działalność dydaktyczną jako kompetentnych medialnie „pośredników” między kulturami. A tym samym w celowy i systematyczny sposób pomagało im w tworzeniu repertuaru własnych strategii podnoszenia kompetencji (w tym kompetencji interkulturowej) nabytych w ramach przygotowania do wykonywania zawodu nauczyciela i inicjowało w ten sposób proces nieustającego samodoskonalenia. Można założyć, że przyczyniłoby się to także do optymalizacji procesu rozwoju kompetencji uczniów, którzy w ramach edukacji szkolnej w wyniku różnego rodzaju ograniczeń, np. czasowych, finansowych lub organizacyjnych, nie są w stanie w pełni rozwinąć tak złożonej kompetencji, jaką jest kompetencja interkulturowa. Wyposażenie ich $\mathrm{w}$ wiedzę i umiejętności przydatne w zdobywaniu wiedzy o obcych kulturach i doświadczeń w kontaktach z nimi (w tym także z wykorzystaniem mediów) jest niewątpliwie bardzo istotnym celem edukacji językowej.

\section{BIBLIOGRAFIA}

Adamczak-Krysztofowicz, S. 2003. Texte als Grundlage der Kommunikation zwischen Kulturen. Eine Studie zur Kultur- und Landeskundevermittlung im DaFStudium in Polen. Verlag Dr. Kovac: Hamburg.

Bandura, E. 2003. „Rola nauczycieli języków obcych w rozwijaniu kompetencji interkulturowej uczniów szkół średnich“. Neofilolog Nr 23: 63-69.

Biechele, B. 2004. "Medienkompetenz und autonomes Lernen. Analyse und Reflexion empirischer Daten einer Befregung von DaF-Studierenden". [w:] Hans Barkowski, H. i Funk, H. (red.). Lernerautonomie und Fremdsprachenunterricht, Berlin: Cornelsen. 152-173.

Bolten, J. 2007: Interkulturelle Kompetenz. Landeszentrale für politische Bildung Thüringen: Erfurt. 
Byram, M., Morgan, C. 1994. Teaching-and-Learning Language-and-Culture. Clevedon: Multilingual Matters.

Chłopek, Z. 2009. „Nauczanie kultury na lekcjach języka obcego w Polsce: Wyniki badań kwestionariuszowych“. Języki Obce w Szkole Nr 1: 61-68.

Chudak, S. 2007a. Lernerautonomie fördernde Inhalte in ausgewählten Lehrwerken DaF für Erwachsene. Überlegungen zur Gestaltung und zur Evaluation von Lehr- und Lernmaterialien. PETER LANG Europäischer Verlag der Wissenschaften: Frankfurt am Main.

Chudak, S. 2007b. „Der deutsche Film auf Erfolgskurs! Warum nicht auch im Deutsch-als-Fremdsprache-Unterricht?“. [w:] Fremdsprache Deutsch. Heft 36: Sehen $(d)$ lernen. 14-16.

Chudak, S. 2008. „Einsatz der Textsorte Film im Fremdsprachenunterricht. Überlegungen zur Stellung von audiovisuellen Unterrichtsmitteln in neueren Lehrwerken für DaF". Studia Germanica Posnaniensia XXXI, Wydawnictwo Naukowe UAM: Poznań. 113-129.

Chudak, S. 2010a. "Über den Mythos polnischen Brotes... Reflexion über den eigenkulturellen Hintergrund bei angehenden polnischen DaF-Lehrern als Beitrag zur Förderung ihrer interkulturellen kommunikativen Kompetenz. Überlegungen zum vorläufigen Ergebnis eines Seminars". [w:] Myczko, K. (red.). Reflexion als Schlüsselphänomen der gegenwärtigen Fremdsprachendidaktik. Frankfurt am Main: Peter Lang Verlag. 225-236.

Chudak, S. 2010b. „Lehrwerk... oder vielleicht doch Filme? Überlegungen zu den Möglichkeiten effektiver Förderung der interkulturellen kommunikativen Kompetenz im Unterricht DaF durch den Einsatz von Lehrwerken und Filmen“. [w:] Welke, T. i Faistauer, R. (red.). Lust auf Film heißt Lust auf Lernen. Der Einsatz des Mediums Film im Unterricht Deutsch als Fremdsprache. Wien: Praesens Verlag. 61-83.

Chudak, S. 2012a. „Kreative Arbeit mit Bildern im Unterricht DaF. Ein Beitrag zur Förderung der eigenkulturellen Reflexion von Fremdsprachenlernenden und lehrenden". [w:] Adamczak-Krysztofowicz, S. i Stork, A. (red.). Multikompetent - multimeldial - multikulturell? Aktuelle Tendenzen in der DaFLehrerausbildung. Frankfurt am Main: Peter Lang. 195-209.

Chudak, S. 2012b. „Polen im Objektiv deutscher Filmemacher. Überlegungen zum Polen-Image in deutschen Filmproduktionen nach dem Jahr 2000“. [w:] Kolago, L. (red.). Studien zur Deutschkunde/Studia Niemcoznawcze. t. 49: 231-244.

Chudak, S. 2013a. „Körpersprache als Fremdsprache? Nonverbale Aspekte der Kommunikation als Gegenstand der Reflexion im kulturkontrastiv ausgerichteten Unterricht DaF im polnischen Kontext". [w:] Moosmüller, A. i Waibel, I. (red.). Wissenschaftsmobilität und Interkulturelle Kommunikation im deutsch-polnischtschechischen akademischen Kontext. Marburg: Tectum Verlag. 144-157.

Chudak, S. 2013b. „Eigenkulturelle Reflexion im Fremdsprachenunterricht. Zur Stellung und zu den Möglichkeiten der Bewusstmachung eigenkultureller Prägungen der Fremdsprachenlernenden im Kontext der Förderung ihrer interkulturellen Kompetenz". Studia Germanica Posnaniensia XXXIII. Wydawnictwo Naukowe UAM: Poznań. 15-26. 
Chudak, S. 2013c. „Fremdsprachenunterricht in Polen - medial, multimedial, ... omnimedal? Überlegungen zum aktuellen Stand der Fachdiskussion um den Einsatz neuer Informations- und Kommunikationstechnologien im Fremdsprachenunterricht im polnischen Kontext". [w:] Chudak, S. (red.). Fremdsprachenunterricht-omnimedial?, Franfurt am Main: Peter Lang Verlag. 13-32.

Chudak, S. 2013d. „Arbeit mit Filmuntertiteln im Unterricht DaF - Ein Beitrag zur Heranführung an autonomes Lernen?" [w:] Möhring, J., Mackus, N. i Tschirner, E. (red.). MatDaF. LeipZIG WEGE öffnen für Bildung, Beruf und Gesellschaft - mit Deutsch als Fremd- und Zweitsprache. [w druku].

Chudak, S./ Welke, T. 2010. "Thesen zur Arbeit mit Film im Unterricht Deutsch als Fremd- und Zweitsprache". IDV-Magazin zur IDT 2009/ Band 2 (www.idvnetz. org/publikationen/magazin/IDV-Magazin82.pdf). 482-486.

Członkowska-Naumiuk, M. (red.) 2011. Erasmus w Polsce w roku akademickim 2009/2010. Warszawa: Fundacja Rozwoju Systemu Edukacji.

Ester, M. 2007. Medien-(pädagogische) Kompetenz. Schlüsselqualifikation für PädagogInnen? Saarbrücken: VDM Verlag Dr. Müller.

Gabryś-Barker, D. 2006. „Nauczyciele (jeszcze) nieprofesjonalni: Diagnoza problemów (badania kwestionariuszowe)“. Neofilolog Nr 29: 90-99.

Godlewicz-Adamiec, J. 2008. „Uczący języka obcego a przekazywanie wiedzy o kulturze". [w:] Jaroszewska, A. i Torenc, M. (red.). Kultury i języki. poznawać uczyć się - nauczać. Warszawa: Uniwersytet Warszawski. 177-187.

Kelly, M. i Grenfell, M. 2006. European Profile for Language Teacher Education. A Frame of Reference/ Europejski profil kształcenia nauczycieli języków obcych. Materiał pomocniczy - zarys treści kształcenia (Tłumaczenie z języka angielskiego: Ewa Osiecka). Warszawa: CODN.

Luchtenberg, S. 2003. Interkulturelle Medienkompetenz. Eine Aufgabe für den Deutschunterricht. Flensburg: Universität Flensburg.

Luchtenberg, S. 2005. „Medienkompetenz - fremdsprachendidaktische Fragestellungen am Beispiel von DaF und DaZ”. Info DaF 6/2005: 597-609.

Mackiewicz, M. 2006. „Orientacja (inter)kulturowa zajęć języka niemieckiego na poziomie ponadgimnazjalnym - fakty i mity“. Neofilolog Nr 28: 33-39.

Marciniak, I. 2012. „Entwicklung der Medienkompetenz in der Fremdsprachenlehrerausbildung im polnischen Kontext“. [w:] Chudak, S. (red.). Fremdsprachenunterricht-omnimedial?, Franfurt am Main: Peter Lang Verlag. 101-112.

Newby, D., Allan, R., Fenner, A.-B., Jones, B., Komorowska, H., i Soghikyan, K. 2007. Europejskie portfolio dla studentów - przyszłych nauczycieli języków. Narzędzie refleksji w kształceniu nauczycieli języków. (Tłumaczenie z języka angielskiego: Mirosław Pawlak). Warszawa: CODN.

Nowacka, D. 2010. „Kompetencja komunikacyjna nauczyciela języka obcego”. [w:] Wasik, Z. i Wach, A. (red.). Heteronomie glottodydaktyki: Domeny, pogranicza, specjalizacje nauczania języków obcych. Poznań: Wydawnictwo UAM. 262 -276.

Pfeiffer, W. 2000. „Möglichkeiten und Grenzen interkultureller Sprachvermittlung“. GLOTTODIDACTICA XXVIII: 125-139.

Pfeiffer, W. 2001. Nauka języków obcych. Od praktyki do praktyki. Poznań: WAGROS. 
Torenc, M. 2008. „Międzykulturowość jako wyzwanie dla nauczycieli języków obcych“. [w:] Jaroszewska, A. i Torenc, M. (red.). Kultury i języki. poznawać uczyć się - nauczać. Warszawa: Uniwersytet Warszawski. 233-240.

Wilczyńska, W. 2005. „Czego potrzeba do udanej komunikacji interkulturowej?“. [w:] Mackiewicz, M. (red.). Dydaktyka języków obcych a kompetencja kulturowa i komunikacja interkulturowa. Poznań: Wydawnictwo Wyższej Szkoły Bankowej. 15-26.

Wolff, D. 2002. Fremdsprachenlernen als Konstruktion. Grundlagen für eine konstruktivistische Fremdsprachendidaktik. Frankfurt am Main: Peter Lang Verlag.

Wysocka, M. 2003. Profesjonalizm w nauczaniu języków obcych. Katowice: Wydawnictwo Uniwersytetu Śląskiego.

Zawadzka, E. 2004. Nauczyciele języków obcych w dobie przemian. Kraków: Impuls.

Zespół Programu Erasmus w Narodowej Agencji Programu „Uczenie się przez całe życie". 2007. 10 lat Erasmus w Polsce. Wybór danych statystycznych i finansowych. Warszawa: Fundacja Rozwoju Systemu Edukacji. 